BISMA

(Bisnis dan Manajemen)
Volume 13, Issue 2, April 2021, 81-93

ISSN 2549-7790 (Online)

ISSN 1979-7192 (Print)

DOI: 10.26740/bisma.v13n2.p81-93

https://journal.unesa.ac.id/index.php/bisma/index

\title{
The ease of transaction and e-service quality of e-commerce platform on online purchasing decision
}

\author{
Cynthia Hartono ${ }^{1}$, Yunita Budi Rahayu Silintowe ${ }^{2 *}$, \\ Andrian Dolfriandra Huruta ${ }^{3}$ \\ ${ }^{1,2}$ Universitas Kristen Satya Wacana, Indonesia \\ ${ }^{3}$ Chung Yuan Christian University, Taiwan
}

\begin{abstract}
Online business development ease consumers to make purchases. One marketplace that can be consumer choice to shop online is Akulaku. Online purchasing decisions at Akulaku can be influenced by various factors such as ease of transaction and e-service quality. This study aims to analyze the effect of ease of transaction and e-service quality on online purchasing decisions in Akulaku. A total of 104 Akulaku consumers lived across Indonesia as samples were collected by a purposive sampling technique. The data was collected using an online questionnaire with structured questions given to Akulaku consumers. The data were analyzed using multiple regression. The results indicate that the ease of transaction has a positive influence on online purchasing decisions in Akulaku. Besides, the eservice quality also has a positive influence on the online purchasing decisions in Akulaku.
\end{abstract}

Keywords: ease of transaction; e-service quality; online purchasing decisions.

Received: January 16, 2020; Accepted: July 21, 2020; Published: April 22, 2021

*Corresponding author

Email: yunita.silintowe@uksw.edu

To cite this document:

Hartono, C., Silintowe Y. B. R., \& Huruta, A. D. (2021). Ease of transaction and e-service quality of e-commerce platform on online purchasing decision. BISMA (Bisnis dan Manajemen), 13(2), 81-93. https://doi.org/10.26740/bisma.v13n2.81-93.

\section{INTRODUCTION}

Technological improvements are getting more advanced from time to time. Not only a few people can enjoy the sophistication of today's technology, but all people can. Not only used for fun, but technology can now also be used for business purposes, especially internet technology for e-commerce businesses. It impacts society, who initially could only buy and sell conventionally, but now people have become more adept at using internet technology to do e-commerce business. The development in internet technology has required people to use online buying and selling platforms to boost sales more easily and quickly and can provide information to consumers easily (Isyanahapsari \& Nurseto, 2018). 
The development of online businesses ease consumers to purchase goods and services because it is more practical and increase purchasing capacity (Harahap, 2018). One of ecommerce conveniences is the ease of transactions that help consumers to make payment transactions. The ease of transaction enables e-commerce consumers to make payments in various ways and become the most efficient payment method for consumers (Rahmawati, 2019).

However, many consumers do not have a credit card yet still want to buy goods or services with an installment system (Quiserto, 2019). Akulaku is the first marketplace site to implement shopping with easy installment payment transactions without a credit card (Akulaku, 2019). With the ease of installment transactions without a credit card, it is expected to attract and enable consumers who do not have a credit card to shop with an installment system (Quiserto, 2019). Akulaku also provides easy transactions by loans for medical, travel, education, household expenses, special events, and purchasing goods. Other transaction facilities at Akulaku are credit purchases, electricity payments, water bill payments, and airplane ticket purchases (Akulaku, 2019). The ease of transaction provided to consumers makes the consumers happier to shop online.

Moreover, some marketplace services should be responsive to help the consumer problems during shopping. They can make complaints while making purchases through customer service available in each marketplace, such as Blog FAQ, Live Chat, Social Media, Telephone, and E-mail (Mustikasari, 2017). If the quality of electronic services provided to consumers is excellent, the consumers will feel comfortable and satisfied to shop at the marketplace site.

However, many marketplaces disappoint their consumers. According to the Indonesian Consumers Foundation (Yayasan Lembaga Konsumen Indonesia), there were many consumer complaints against e-commerce. There were 642 complaints from consumers who had made purchases in online media (Julianto, 2018). Table 1 is the complaints ranking list published by the YLKI.

Table 1. The Ranking of Online Site Sales Complaints in 2017

\begin{tabular}{|c|c|c|}
\hline No & Sales Site & Number of Complaints \\
\hline 1. & Lazada & 18 \\
\hline 2. & Akulaku & 14 \\
\hline 3. & Tokopedia & 11 \\
\hline 4. & Bukalapak & 9 \\
\hline 5. & Shopee & 7 \\
\hline 6. & Blibli & 5 \\
\hline 7. & JD.ID & 4 \\
\hline 8. & Elevenia & 3 \\
\hline
\end{tabular}

Source: Julianto (2018)

Based on Table 1, Akulaku is in the second rank with 14 complaints. The complaints level derived from several cases such as a consumer purchased goods did not arrive until the installment invoice received, although the consumer had contacted Akulaku and got zero response (Rachman, 2018). On June 4, 2018, another consumer had paid the installment bill, but in his Akulaku account, the bill had not yet been updated, so the consumer made a 
complaint (Akbar, 2018). However, there was no progress, and the consumer was still being called by the billing party to pay off the installment. Another problem was one consumer had paid the bill, but in his Akulaku account, the amount did not match the original bill and nor decrease. Then, the consumer contacted Akulaku, but there was no response (Wilyusdinik, 2017).

Another example of complaints is that once a consumer purchased goods and had paid the down payment installments, the delivery status was not processed. Akulaku also did not provide consumers information, but when goods arrived, it turned out that the goods did not match what the consumers ordered. The consumers had also contacted Akulaku, but no one responded to the complaint (Faturahman, 2017). However, on the following day, the amount of installment agreed previously suddenly changed and became more expensive, yet there was no explanation from Akulaku (Megasari, 2017).

It is mandatory for e-commerce parties to pay attention to the factors influencing the ease of transaction and e-service quality. According to Turban et al. (2010), the transaction should be implemented as simple and easy as possible without going through a process that can make it difficult for users to process transactions. A previous study claimed that the ease of transaction was the most dominant variable and influenced online purchasing decisions (Lestari \& Iriani, 2018). Rohmawati (2019) and Suharni (2019) also suggested that the ease of transaction influenced the consumers in making online purchase decisions. However, Priscanandia (2019) showed that transaction ease did not affect purchasing decisions. Thus, there is a research gap in previous researches about the effect of ease of transaction on online purchasing decisions.

According to Chang et al. (2009), e-service quality refers to a service from a website that provides consumers' facilities to shop efficiently and effectively. It is also considered highly influential on the online purchasing decisions where its existence can make online services attractive and effective so that it helps the marketplaces to obtain high purchasing decisions from the consumers (Rozi \& Harti, 2017). Previous researches related to e-service quality have focused on customer satisfaction (Bressolles et al., 2014; Finn, 2011; Ali et al., 2017; Ma Sabiote et al., 2012; Zavareh et al., 2012), consumer loyalty (Yen \& Lu, 2008), and both of them (Al-dweeri et al., 2017; Chang et al., 2009; Ghane et al., 2011; Sheng \& Liu, 2010). Based on the gaps in the previous research results and the phenomena explained earlier, it is essential to study the online purchasing decision and the factors influencing them, including the ease of transaction and e-service quality.

\section{The Influence of Ease of Transaction on Online Purchasing Decision}

The ease of transaction can be defined as the level where someone believes that a system can be used easily without requiring a lot of effort (Renny \& Siringoringo, 2013; Alwafi \& Magnadi, 2016). Similarly, Turban et al. (2010) agreed that the ease of transaction is a method that can be used very easily through a fast process of making transactions so that the consumers do not experience difficulties in making transactions. Furthermore, the purchasing decision is defined as selecting an action based on various alternative options (Sangadji \& Supiah, 2013). It is a stage in the decision-making process which the consumers make a purchase (Kotler \& Armstrong, 2012). 
Previous research found that there was an influence of the ease of transaction on the online purchasing decision (Lestari \& Iriani, 2018; Rohmawati, 2019; Suharni, 2019). With various ways of making online transactions, the ease of transaction will be considered more useful for consumers in shopping. The consumers will prefer a way that is more practical and beneficial. Therefore, a hypothesis that can be proposed in this study is as follows:

H1: In online sales, the ease of transaction has a positive influence on online purchasing decision.

\section{The Influence of E-Service Quality on Online Purchasing Decision}

E-service quality (e-servqual) is defined as the extent to which facilitates efficient and effective services in purchasing and product delivery of virtual marketplace (Lee \& Lin, 2005; Rafiq et al., 2012). Similarly, Ladhari (2010) defined e-service quality as a website that provides services for consumers in doing online services (electronic services) such as online shopping and looking up needed information. Also, the e-service quality has several indicators such as efficiency (the ability of consumers to find good websites), reliability (the ability of a website to provide accurate and precise information to consumers), responsiveness (the ability of website services to respond to consumer problems in making purchases and providing fast services to consumers), fulfillment (the ability to provide services by providing the product desired by consumers promptly), and privacy (the ability of website service to protect consumers' data) (Saha \& Zhao, 2005).

Meanwhile, a purchasing decision can be defined as a decision that involves several options. With a good perception from the consumers of the product or service quality, the consumers will be able to make decisions in the purchasing process (Xu et al., 2013; Kundu \& Datta, 2015; Kotler \& Armstrong, 2012). Previous studies on e-service quality significantly influence online purchasing decisions (Nasser et al., 2015; Rozi \& Harti, 2017; Rita \& Farisa, 2019; Dapas et al., 2019). The e-service quality is a determinant for a marketplace to maintain the e-commerce process effectiveness. The existence of a good e-service quality will have a positive impact on the marketplace. It is possible because the consumers will feel more comfortable and become more frequent in making purchasing decisions. Therefore, the following is a hypothesis that can be proposed:

$\mathrm{H} 2$ : In online sites, e-service quality has a positive influence on purchasing decision.

\section{METHODS}

The population of this study is all unknown numbers of Akulaku consumers in Indonesia. Meanwhile, the sample is a sub-group of the population selected to participate in the study. In this study, the sampling technique used was purposive sampling. The criteria for respondents involved in this study were consumers who had already made transactions in Akulaku. In this study, the researchers involved a total of 104 respondents.

Several indicators of the research variables are presented in table 2. The data was collected by an online and structured questionnaire (in Google Forms) with five Likert scale distributed to Indonesia's Akulaku consumers. The respondents were expected to answer questions well so that the researchers could get responses from the consumers on factors influencing online purchasing decisions at Akulaku. 
Hartono, C., Silintowe, Y. B. R., \& Huruta, A. D.

Ease of transaction and e-service quality of e-commerce platform on online purchasing decision

Table 2. Definition of Operational Variables

\begin{tabular}{|c|c|c|c|c|}
\hline No & Variable & Definition & Indicator & Source \\
\hline 1. & $\begin{array}{l}\text { Ease of } \\
\text { Transaction }\end{array}$ & $\begin{array}{l}\text { Ease of transaction is a } \\
\text { method that can be used } \\
\text { very easily through a fast } \\
\text { process of making } \\
\text { transactions so that } \\
\text { consumers do not } \\
\text { experience difficulties in } \\
\text { making transactions } \\
\text { (Turban et al., 2010). }\end{array}$ & $\begin{array}{l}\text { Ease of navigation, easy } \\
\text { to understand, ease of } \\
\text { payment, and flexible } \\
\text { transaction options. }\end{array}$ & $\begin{array}{l}\text { Lestari \& } \\
\text { Iriani } \\
(2018)\end{array}$ \\
\hline 2. & $\begin{array}{l}\text { E-Service } \\
\text { Quality }\end{array}$ & $\begin{array}{l}\text { E-servqual is the service } \\
\text { quality of a website that } \\
\text { can effectively and } \\
\text { efficiently provide services } \\
\text { for consumers in doing } \\
\text { online services (electronic } \\
\text { services) such as online } \\
\text { shopping and looking up } \\
\text { needed information } \\
\text { (Ladhari, 2010). }\end{array}$ & $\begin{array}{l}\text { Efficiency, reliability, } \\
\text { responsiveness, } \\
\text { fulfillment, and privacy. }\end{array}$ & $\begin{array}{l}\text { Saha \& } \\
\text { Zhao } \\
(2005)\end{array}$ \\
\hline 3. & $\begin{array}{l}\text { Purchasing } \\
\text { Decision }\end{array}$ & $\begin{array}{l}\text { The purchasing decision is } \\
\text { a stage in the decision- } \\
\text { making process where } \\
\text { consumers make a purchase } \\
\text { (Kotler \& Armstrong, } \\
\text { 2012). }\end{array}$ & $\begin{array}{l}\text { A decision about the type } \\
\text { of product, a decision } \\
\text { about the form of product, } \\
\text { a decision about brands, a } \\
\text { decision about the seller, a } \\
\text { decision about the number } \\
\text { of products, a decision } \\
\text { about the time of } \\
\text { purchase, and a decision } \\
\text { about payment method }\end{array}$ & $\begin{array}{l}\text { Kotler } \\
(2012)\end{array}$ \\
\hline
\end{tabular}

This study used the multiple linear regression techniques in SPSS. This study applies a crosssection manner. Therefore, the researchers used the ordinary least squares method. This method can be explained through equation (1).

$Y_{i}=\beta_{0}+\beta_{1} X_{1 i}+\beta_{2} X_{2 i}+\varepsilon_{i}$

Note:

$Y_{i} \quad=$ Perception of online purchasing decision from respondents to $\mathrm{i}$

$X_{1 i}=$ Perception of ease of transaction from respondents to $\mathrm{i}$

$X_{2 i}=$ Perception of e-service quality from respondents to $\mathrm{i}$

$\beta_{0}=$ Intercept

$\beta_{1}, \beta_{2}=$ Slope

$\varepsilon_{i}=$ Error term from respondents to $\mathrm{i}$

Furthermore, the multiple linear regression analysis requires validity and reliability tests as well as classical assumption tests. The classical assumption test includes normality, multicollinearity, and heteroscedasticity test. 


\section{RESULT AND DISCUSSION \\ Result of Validity and Reliability Test}

The validity test on the main research questionnaire was based on all 104 responses from the respondents who had made transactions at Akulaku. All empirical indicators of each variable have a corrected item-total correlation value or r-count $>$ r-table $(0.162)$ so that the empirical indicator is considered valid (Appendix 1). The result of each variable's reliability test, which is an integral part of the validity test and that all $r$-alpha values of each variable are considered reliable because they have r-alpha value of $>0.70$ (Appendix 2).

\section{Result of Normality Test}

A normality test was done to residual variables in the study using the KolmogorovSmirnov (K-S) non-parametric statistical test. The result of the normality test shows that the value of Kolmogorov-Smirnov (K-S) is 1.072 with a significant value of $0.201>0.05$ (Appendix 3). Thus, the residuals from the data have a normal distribution.

\section{Result of Multicollinearity Test}

The multicollinearity test of independent variables (ease of transaction and e-service quality) was done by considering the regression output result's Tolerance and VIF. The result of multicollinearity shows the tolerance value for the ease of transaction and e-service quality variable is $>0.10$ (Appendix 4). Therefore, there is no multicollinearity among the independent variables. Meanwhile, based on the VIF value, it appears that the VIF value for the ease of transaction and e-service quality variables is $<10$. Thus, there is no multicollinearity among the independent variables.

\section{Result of Heteroscedasticity Test}

The heteroscedasticity test of the research variables used the glejser test. The result shows that the parameter coefficient for each independent variable is not significant (sig. > 0.05), which is 0.164 for ease of transaction and 0.097 for e-service quality (Appendix 5). Therefore, heteroscedasticity does not occur in the regression model.

\section{Result of Hypothesis Testing}

The hypothesis testing was done after all classical assumptions were met. The data were analyzed using a multiple regression test. The result shows that the ease of transaction and eservice quality has a positive influence on online purchasing decision at Akulaku in Table 3. Based on the regression analysis carried out, a regression equation can be proposed in equation (2).

$\hat{\mathrm{Y}}=7.083+0.603 \mathrm{X}_{1}+0.377 \mathrm{X}_{2}$

Table 3. Multiple Regression Result

\begin{tabular}{lccc}
\hline \multicolumn{1}{c}{ Variable } & B & t-statistic*** & Sig. \\
\hline Ease of Transaction & 0,603 & $4,442^{*}$ & 0,000 \\
E-Service Quality & 0,377 & $3,403^{*}$ & 0,001 \\
\hline
\end{tabular}


The interpretation of the result follows, the regression coefficient of ease of transaction of 0.603 indicates that each one-unit increase of the ease of transaction will also increase the online purchasing decision at Akulaku as many as 0.603 units and the regression coefficient of the e-service quality of 0.377 indicates that each one-unit increase of the e-service quality will also increase the online purchasing decision at Akulaku as many as 0.377 units.

The influence of the independent variables on online purchasing decisions in Akulaku can be seen from the $\mathrm{R}^{2}$ value of 0.319 , which means that $31.9 \%$ of the influence of purchasing decisions can be explained by the ease of transaction e-service quality variable. Meanwhile, the rest, $68.1 \%$, can be explained by other variables not included in the model.

\section{Discussion}

The regression test result shows that the ease of transaction positively influences the online purchasing decision at Akulaku or H1 is empirically supported. The influence shown has a positive direction, which explains that the easier the consumers' transaction, the higher the online purchasing decision at Akulaku. However, on the other hand, the less comfortable the transaction, the lower the online purchasing decision at Akulaku.

On average, the consumers thought that making payments in marketplaces was considered manageable. One of the parameters of ease of transaction which became the reasons for consumers to online shopping was the availability of easy payment method options at Akulaku. Besides, Akulaku was a marketplace that enable consumers to shop by credit without having a credit card. The consumers might shop any products as long as the price was not higher than the credit limit of Akulaku consumers. Akulaku also provided convenience in terms of down payment installments for its users. Customers can pay through ATM or merchants such as Indomaret or Alfamart. These easy payment method options at Akulaku ultimately influenced the online purchasing decision at Akulaku.

Furthermore, the online purchasing decision at Akulaku could have been low if the managers did not maintain the ease of transaction. For example, some consumers had paid the installment bills, but Akulaku did not update their customer account. The consumers felt disadvantaged after deciding to purchase products at Akulaku, but the amount of installment agreed earlier had changed to be more expensive on the next day. These cases might decrease the online purchasing decision at Akulaku.

The positive influence shown by the relationship between the ease of transaction and online purchasing decision found in this study supports Cho \& Sagynov (2015) about ease of use impact on e-commerce purchase intention; Lestari \& Iriani (2018) research about how convenience online transactions are operated; and Suleman et al. (2019) about the influence of ease of use transaction on fashion purchase intention. Instructions on how to make an online transaction, starting from the procedure and features to fill out the purchasing form, would ease the consumers to shop online. The finding of this study also supports previous research findings by Renny \& Siringoringo (2013), Hansen et al. (2018), and Nazarudin \& Pela (2016), where they found a significant positive effect on the ease of transaction on an online purchasing decision.

Furthemore, the regression test result shows that e-service quality has a positive influence on the online purchasing decision at Akulaku or $\mathrm{H} 2$ is empirically supported. This positive 
influence explains that the better the consumers' e-service quality, the higher the online purchasing decision at Akulaku.

On average, the consumers considered the e-service quality in marketplaces was good enough. One of e-service quality parameters at Akulaku is clear information on the website. It was highly needed by the consumers when they wanted to make the transaction in a marketplace. On the Akulaku website, the consumers could easily find exact information, starting from how to register in the Akulaku application, the requirements needed to use the Akulaku credit service, application procedure of Akulaku credit account, purchasing procedure of Akulaku credit, and Akulaku's complaint system.

Furthermore, the positive influence shown by the relationship between the e-service quality and online purchasing decision found in this study confirms a statement by Rozi \& Harti (2017), which mentioned that the online environment's service quality was an essential determinant in terms of the effectiveness of e-commerce process. The development of e-service quality helped the online service to be more effective and attractive, thus helping the company to achieve the highest level of achievement on purchasing decisions. This finding is also in line with Ismayanti et al. (2015), which confirmed the positive influence of e-service quality on purchasing decisions.

\section{CONCLUSION}

Based on the results and discussion, the ease of transactions and e service quality have a positive influence on online purchase decisions at Akulaku. Thus, the easier the transactions made by consumers in making online purchases at Akulaku, the higher their purchasing decision. Similarly, the better the consumers' e-service quality when making online purchases at Akulaku, the higher the consumer's purchasing decision.

This study has several limitations to address. This study does not provide information about what product categories often bought at Akulaku. Secondly, this study examined the quality of the e-service in online stores in general, not based on segments of products sold in the online shop. In some product segments, the measurement used in this study may not be applicable. A variety of product segment and/or other industries should be considered in future research to ensure that the measurement is equally effective for particular product categories. The measurement may have to be adjusted in other industry settings.

\section{REFERENCES}

Akbar. (2018). “Tagihan Akulaku sudah Dibayar, Masih Ditelepon Bagian Penagihan”. Retrived January 52020 from https://news.detik.com/suara-pembaca/d4082018/tagihan-akulaku-sudah-dibayar-masih-ditelepon-bagian-penagihan.

Akulaku. (2019). "Shop On Installment Without Credit Card”. Retrived January 52020 from https://play.google.com/store/apps/details?id=io.silvrr.installment\&hl=en.

Al-dweeri, R. M., Obeidat, Z. M., Al-dwiry, M. A., Alshurideh, M. T., \& Alhorani, A. M. (2017). The Impact of E-Service Quality and E-Loyalty on Online Shopping: Moderating Effect of E-Satisfaction and E-Trust. International Journal of Marketing Studies, 9(2), 92. https://doi.org/10.5539/ijms.v9n2p92. 
Ali, M., Asmi, F., Rahman, M. M., Malik, N., \& Ahmad, M. S. (2017). Evaluation of EService Quality through Customer Satisfaction (a Case Study of FBR E-Taxation). Open Journal of Social Sciences, 05(09), 175-195. https://doi.org/10.4236/jss.2017.59013.

Alwafi, F. \& Magnadi, R. H. (2016). Pengaruh Persepsi Keamanan, Kemudahan Bertransaksi, Kepercayaan terhadap Toko, dan Pengalaman Berbelanja terhadap Minat Beli secara Online pada Situs Jual Beli Tokopedia.com. Diponegoro Journal of Management, 5(2), 1-15. https://ejournal3.undip.ac.id/index.php/djom/article/view/13857/13407.

Bressolles, G., Durrieu, F., \& Senecal, S. (2014). A Consumer Typology Based on E-Service Quality and E-Satisfaction. Journal of Retailing and Consumer Services, 21(6), 889-896. https://doi.org/10.1016/j.jretconser.2014.07.004.

Chang, H. H., Wang, Y. H., \& Yang, W. Y. (2009). The Impact of E-Service Quality, Customer Satisfaction and Loyalty on E-Marketing: Moderating Effect of Perceived Value. Total Quality Management and Business Excellence, 20(4), 423-443. https://doi.org/10.1080/14783360902781923.

Cho, Y. C., \& Sagynov, E. (2015). Exploring Factors that Affect Usefulness, Ease of Use, Trust, and Purchase Intention in the Online Environment. International Journal of Management \& Information Systems, 19(1), 21-36. https://doi.org/10.19030/ijmis.v19i1.9086.

Dapas, C. C., Sitorus, T., Purwanto, E., \& Ihalauw, J. J. (2019). The effect of service quality and website quality of Zalora. com on purchase decision as mediated by purchase intention. Quality - Acces to Success, 20(169), 87-92. https://www.srac.ro/calitatea/en/arhiva/2019/QAS_Vol.20_No.169_Apr.2019.pdf.

Faturahman, D. (2017). "Sudah Bayar Uang Muka, Status Pesanan di Akulaku tidak Berubah". Retrived January 52020 from https://news.detik.com/suara-pembaca/3515228/sudahbayar-uang-muka-status-pesanan-di-akulaku-tidak-berubah.

Finn, A. (2011). Investigating the Non-Linear Effects of E-Service Quality Dimensions on Customer Satisfaction. Journal of Retailing and Consumer Services, 18(1), 27-37. https://doi.org/10.1016/j.jretconser.2010.09.002.

Ghane, S., Fathian, M., \& Gholamian, M. R. (2011). Full Relationship among E-Satisfaction, E-Trust, E-Service Quality, and E-Loyalty: The Case of Iran E-Banking. Journal of Theoretical and Applied Information Technology, 33(1), 1-6. http://www.jatit.org/volumes/Vol33No1/thirtythird_volume_1_2011.php.

Hansen, J. M., Saridakis, G., \& Benson, V. (2018). Risk, Trust, and the Interaction of Perceived Ease of Use and Behavioral Control in Predicting Consumers' use of Social Media for Transactions. Computers in Human Behavior, 80, 197-206. https://doi.org/10.1016/j.chb.2017.11.010.

Harahap, N. (2018). Pengaruh Transaksi Non Tunai menggunakan Layanan Virtual Bisnis terhadap Kepuasan Konsumen pada PT. Indomarco Prismatama Cabang Medan. Jurnal Bisnis Net, 1(1). http://jurnal.dharmawangsa.ac.id/index.php/bisnet/article/view/42. 
Ismayanti, N. W. N., Suardana, I. W., \& Negara, I. M. K. (2015). Pengaruh Kepercayaan dan E-Service Quality terhadap Keputusan Pembelian Akomodasi di Bali pada Situs Booking.com. Jurnal IPTA, 3(1), 56-61. https://doi.org/10.24843/IPTA.2015.v03.i02.p10.

Isyanahapsari, S. \& Nurseto, S. (2018). Pengaruh Periklanan dan Kualitas Pelayanan terhadap Keputusan Pembelian secara Online pada Situs Belanja Online (Studi Kasus pada Pengguna E-commerce Elevania di Kota Semarang). 7(1), 1-12. https://ejournal3.undip.ac.id/index.php/jiab/article/view/19122.

Julianto, P. A. (2018). "Toko Online Paling Banyak Diadukan Konsumen ke YLKI, Ini Daftarnya". $\quad$ Retrived 5 January 2020 from https://ekonomi.kompas.com/read/2018/01/19/171756726/toko-online-paling-banyakdiadukan-konsumen-ke-ylki-ini-daftarnya?page=all.

Kotler, P. \& Armstrong, G. (2012). Principles of Marketing. New Jersey: Pearson Education Limited.

Kundu, S., \& Datta, S. K. (2015). Impact of Trust on the Relationship of E-service Quality and Customer Satisfaction. EuroMed Journal of Business, 10(10), 21-46. https://doi.org/10.1108/EMJB-10-2013-0053.

Ladhari, R. (2010). Developing E-Service Quality Scales: A Literature Review. Journal of Retailing and Consumer Services, 17(6), 464-477. https://doi.org/10.1016/j.jretconser.2010.06.003.

Lee, G. G. \& Lin, H. F. (2005). Customer Perceptions of E-Service Quality in Online Shopping. International Journal of Retail and Distribution Management, 33(2), 161-176. https://doi.org/10.1108/09590550510581485.

Lestari, N. A. \& Iriani, S. S. (2018). Pengaruh Kepercayaan dan Kemudahan Transaksi terhadap Keputusan Pembelian Secara Online pada Situs Mataharimall.com. Jurnal Ilmu $\begin{array}{llll}\text { Manajemen } & \text { (JIM), 6(1), } & \text { 1-8. }\end{array}$ https://jurnalmahasiswa.unesa.ac.id/index.php/jim/article/view/22568.

Ma E-Satisfaction: The Moderating Effect of Culture. Online Information Review, 36(2), 157-174. https://doi.org/10.1108/14684521211229011.

Megasari, D. (2017). “Harga Naik Tanpa Konfirmasi, Cicilan Akulaku Berubah”. Retrived January 52020 from https://news.detik.com/suara-pembaca/d-3611168/harga-naiktanpa-konfirmasi-cicilan-akulaku-berubah.

Mustikasari, I. (2017). "Pentingnya Costumer Service dalam Situs Jual Beli Online”. Retrived January 52020 from https://iprice.co.id/trend/insights/belanja-online-jaman-now-tidakperlu-skeptis-dengan-costumer-service/.

Nasser, M. A., Islam, R., Zainal Abidin, I. S., Azam, M., \& Prabhakar, A. C. (2015). Analysis of E-service Quality through Online Shopping. Research Journal of Business Management, 9(3), 422-442. https://doi/org/10.3923/rjbm.2015.422.442. 
Nazarudin, H. \& Pela, Y. (2016). Pengaruh Kemudahan dan Kualitas Informasi terhadap Keputusan Pembelian secara Online di Situs D’BC Network Orifline (Studi pada Masyarakat Fatufeto Kota Kupang). BISMAN Jurnal Bisnis dan Manajemen, 2(2), 112121. http://www.jurnal.pnk.ac.id/index.php/bisman/article/view/59.

Priscanandia, R. (2019). Analisis Pengaruh Diskon, Ulasan, dan Kemudahan dalam Bertransaksi pada Keputusan Pembelian Tiket Hotel pada TRAVELOKA. Thesis, Universitas Bakrie, Jakarta, Indonesia. Retrived January 52020 from http://repository.bakrie.ac.id/2615/.

Quiserto, R. (2019). “15 Cicilan Tanpa Kartu Kredit PayLater Terbaik, Cepat dan Terpercaya”. Retrived 5 January 2020 from https://duwitmu.com/kta/cicilan-tanpa-kartu-kredit-cepatterpercaya/amp/.

Rachman, A. (2018). "Kecewa dengan Akulaku, Barang Belum Diterima Sudah Muncul Tagihan - Media Konsumen". Retrived January 5 2020 from https://mediakonsumen.com/2018/06/13/surat-pembaca/kecewa-akulaku-barang-belumditerima-sudah-muncul-tagihan.

Rafiq, M., Lu, X., \& Fulford, H. (2012). Measuring Internet retail service quality using E-SQUAL. Journal of Marketing Management, 28(9-10), 1159-1173. https://doi.org/10.1080/0267257X.2011.621441.

Rahmawati, W. (2019). “Transaksi Tanpa Uang Tunai Makin Populer di Indonesia”. Retrived January 52020 from https://keuangan.kontan.co.id/news/transaksi-tanpa-uang-tunaimakin-populer-di-indonesia.

Renny, Guritno, S., \& Siringoringo, H. (2013). Perceived Usefulness, Ease of Use, and Attitude Towards Online Shopping Usefulness Towards Online Airlines Ticket Purchase. Procedia - Social and Behavioral Sciences, 81, 212-216. https://doi.org/10.1016/j.sbspro.2013.06.415.

Rita, P., Oliveira, T., \& Farisa, A. (2019). The impact of e-service quality and customer satisfaction on customer behavior in online shopping. Heliyon, 5(10), e02690.

Rohmawati, Y. (2019). Analisis Pengaruh Gaya Hidup, Persepsi Keamanan, Kemudahan Bertransaksi, Harga serta Keragaman Produk terhadap Keputusan Pembelian Konsumen LAZADA MOBILE Marketplace di Kudus. Skripsi, Universitas Muria Kudus, Central Java, Indonesia. Retrived 5 January 2020 from http://eprints.umk.ac.id.

Rozi, I. F. \& Harti. (2017). Pengaruh E-Service Quality terhadap Keputusan Pembelian Tiket Kereta Api Online. Jurnal Pendidikan Tata Niaga (JPTN), 1(2), 118-112. https://jurnalmahasiswa.unesa.ac.id/index.php/jptn/article/view/18432/16807.

Saha, P. \& Zhao, Y. (2005). Relationship between Online Service Quality and Customer Satisfaction A Study in Internet Banking. Thesis, Lulea University of Technology, Sweden. Retrived 5 January 2020 from http://www.divaportal.org/smash/record.jsf?pid=diva2\%3A1030797\&dswid=3919.

Sangadji, E. M. \& Supiah. (2013). Perilaku Konsumen. Yogyakarta: CV Andi. 
Sheng, T. \& Liu, C. (2010). An Empirical Study on The Effect of E-Service Quality on Online Customer Satisfaction and Loyalty. Nankai Business Review International, I(3), 273283. https://doi.org/10.1108/20408741011069205.

Suharni. (2019). Pengaruh Promosi dan Kemudahan Bertransaksi terhadap Keputusan Melakukan Pembelian Online. Thesis, Institut Agama Islam Negeri Palopo, South Sulawesi, Indonesia. $\quad$ Retrived January 52020 from http://repository.iainpalopo.ac.id/id/eprint/1644/1/SUHARNI.pdf.

Suleman, D., Zuniarti, I., \& Sabil, S. (2019). Consumer Decisions toward Fashion Product Shopping in Indonesia: The effects of Attitude, Perception of Ease of Use, Usefulness, and Trust. Management Dynamics in the Knowledge Economy, 7(2), 133-146. http://www.managementdynamics.ro/index.php/journal/article/view/302.

Turban, E., David, K., Jae, L., Ting, P., \& Decorrah, C. (2010). Electronic Commerce: Managerial Perspective Global (6 ed). New Jersey: Pearson.

Xu, J., Benbasat, I., \& Cenfetelli, R. T. (2013). Integrating service quality with system and information quality: an empirical test in the e-service context. MIS quarterly, 777-794. http://misq.org/integrating-service-quality-with-system-and-information-quality-andempirical-test-in-the-e-service-context.html.

Wilyusdinik, R. (2017). "Sistem Akulaku Bermasalah, Analisa Masalah Lambat - Media Konsumen". $\quad$ Retrived January 45020 from https://mediakonsumen.com/2017/07/12/surat-pembaca/sistem-akulaku-bermasalahanalisa-masalah-lambat.

Yen, C. H. \& Lu, H. P. (2008). Effects of E-Service Quality on Loyalty Intention: An Empirical Study in Online Auction. Managing Service Quality, 18(2), 127-146. https://doi.org/10.1108/09604520810859193.

Zavareh, F. B., Ariff, M. S. M., Jusoh, A., Zakuan, N., Bahari, A. Z., \& Ashourian, M. (2012). E-Service Quality Dimensions and Their Effects on E-Customer Satisfaction in Internet Banking Services. Procedia - Social and Behavioral Sciences, 40, 441-445. https://doi.org/10.1016/j.sbspro.2012.03.213. 
Hartono, C., Silintowe, Y. B. R., \& Huruta, A. D.

Ease of transaction and e-service quality of e-commerce platform on online purchasing decision

Appendix 1. Validity Test Result of Research Questionnaire

\begin{tabular}{lccc}
\hline \multicolumn{1}{c}{ Variable } & $\begin{array}{c}\text { Empirical } \\
\text { Indicator }\end{array}$ & $\begin{array}{c}\text { Corrected item- } \\
\text { total correlation }\end{array}$ & Result \\
\hline \multirow{3}{*}{ Ease of Transaction } & ET1 & 0.586 & Valid \\
& ET2 & 0.533 & Valid \\
& ET3 & 0.578 & Valid \\
KT4 & 0.602 & Valid \\
E-Service Quality & eSQ1 & 0.539 & Valid \\
& eSQ2 & 0.608 & Valid \\
& eSQ3 & 0.493 & Valid \\
& eSQ4 & 0.554 & Valid \\
& eSQ5 & 0.569 & Valid \\
& eSQ6 & 0.438 & Valid \\
Online Purchasing & OPD1 & 0.599 & Valid \\
Decision & OPD2 & 0.557 & Valid \\
& OPD3 & 0.684 & Valid \\
& OPD4 & 0.568 & Valid \\
& OPD5 & 0.585 & Valid \\
& OPD6 & 0.534 & Valid \\
& OPD7 & 0.636 & Valid \\
\hline
\end{tabular}

Appendix 2. Reliability Test Result of The Main Research Questionnaire

\begin{tabular}{lcc}
\multicolumn{1}{c}{ Variable } & $\boldsymbol{r}$-Alpha & Conclusion \\
\hline Ease of Transaction & 0.772 & Reliable \\
E-Service Quality & 0.783 & Reliable \\
Online Purchasing Decision & 0.839 & Reliable \\
\hline
\end{tabular}

Appendix 3. Result of Normality Test

\begin{tabular}{lc}
\hline & Unstandardized Residual \\
\hline Kolmogorov-Smirnov Z & 1.072 \\
Asymp. Sig (2-tailed) & 0.201 \\
\hline
\end{tabular}

Appendix 4. Result of Multicollinearity Test

\begin{tabular}{lcc}
\hline \multicolumn{1}{c}{ Variable } & Tolerance & VIF \\
\hline Ease of Transaction & 0.882 & 1.133 \\
E-Service Quality & 0.882 & 1.133 \\
\hline
\end{tabular}

Appendix 5. Result of Heteroscedastcity

\begin{tabular}{lcc}
\hline \multicolumn{1}{c}{ Variable } & t-statistic & Sig. \\
\hline Ease of Transaction & 1.403 & 0.164 \\
E-Service Quality & -1.674 & 0.097 \\
\hline
\end{tabular}

